\title{
Anti-urbanism in Flanders: the political and social consequences of a spatial class struggle strategy
}

Les attitudes anti-urbaines en flandre: conséquences politiques et sociales d'une strategie spatiale de lutte des classes

\section{Christian Kesteloot and Filip De Maesschalck}

\section{(2) OpenEdition}

Journals

Electronic version

URL: http://journals.openedition.org/belgeo/15346

DOI: $10.4000 /$ belgeo. 15346

ISSN: 2294-9135

Publisher:

National Committee of Geography of Belgium, Société Royale Belge de Géographie

Printed version

Date of publication: 30 June 2001

Number of pages: 41-62

ISSN: 1377-2368

\section{Electronic reference}

Christian Kesteloot and Filip De Maesschalck, « Anti-urbanism in Flanders: the political and social consequences of a spatial class struggle strategy », Belgeo [Online], 1-2 | 2001, Online since 30 November 2001, connection on 19 April 2019. URL : http://journals.openedition.org/belgeo/15346 ; DOI : 10.4000/belgeo.15346

This text was automatically generated on 19 April 2019

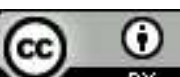

Belgeo est mis à disposition selon les termes de la licence Creative Commons Attribution 4.0 International. 


\section{Anti-urbanism in Flanders: the political and social consequences of a spatial class struggle strategy}

Les attitudes anti-urbaines en flandre: conséquences politiques et sociales d'une strategie spatiale de lutte deS classes

Christian Kesteloot and Filip De Maesschalck

1 Measured by the active population in industry and the services sector, Flanders is one of the most urbanised areas in the world - yet Flemings have no idea what a large town is. To the 200,000 Flemish commuters who make the daily trek to work in Brussels, the city is dirty, alien and dangerous. They only know the route from the office to the car park or to the station and vice versa. Three thousand young people study at the EHSAL (an economic high school) in Brussels, of whom barely 600 are in digs - not in Brussels, but chiefly in Leuven or Ghent. To them, the commuting time and associated costs are more than compensation for the idea that Brussels is big, unsafe and expensive. In a report to mark the start of the academic year, a Kulak student in Kortrijk explained that it was a nice place to study ("because everybody knows everybody"), much nicer than in the big city where they would feel lost and would miss the safety and security. To them, the big city is Leuven. In their minds, Brussels is probably a kind of hell.

The Flemish government ${ }^{1}$ showed discretion in choosing Brussels rather than Antwerp or, worse still, Mechelen - as the capital, but it comes down to no more than the presence of certain institutions and a certain lip-service to the Brussels Flemings. By way of illustration, the Social Impulse Fund, a 7 billion Fund of the Flemish Community distributed to the municipalities to fight social exclusion envisaged a few hundred millions for Brussels, compared to more than 2 billion for Antwerp and 1 billion for Ghent ${ }^{2}$. Because of suburbanisation, the Flemings of Brussels are a dying breed. At a hearing in the Flemish Parliament on the Flemish policy plan for Brussels, the big-wigs in some of the leading Flemish cultural movements advocated calling a halt to the development of 
Brussels (in the first instance its international functions) and the protection of Brussels Flemings by offering them pure Flemish institutions in all areas of collective consumption. The Vlaams Blok is also of this opinion and wishes to demote Brussels to a kind of protected area, where poor francophone Brussels' natives can also enjoy the generous help of the Flemish people - on condition that they first undermine the Belgian federal model by granting the Vlaams Blok a Flemish majority on the Brussels Capital Council ${ }^{3}$. Not one hair on the heads of these Flemings believes that, as the international charisma of Brussels increases, it represents more of an asset to Flemish emancipation because its culture has a megaphone there, which reaches much further than all the other Flemish cities put together and because culture can grow and blossom there much more intensively as a result of interaction with a cosmopolitan, multicultural environment.

Clearly, an anti-urban attitude prevails in Flanders, which becomes more intense the larger the town, reaching a peak in Brussels. Of course, community relations also play their part in the Flemish aversion for Brussels. In the Belgian historical context, Brussels has proved to be a powerful French acculturation machine, which also extends into Flemish Brabant with suburbanisation (Sieben, Witte and Dockx in Witte, 1993) ${ }^{4}$. However, Brussels is very much the big city, where urban culture is alive, where the rest of the world becomes accessible and tangible and, in particular, a place where wheeling and dealing has more to do with the world economy than with local and regional developments. To a minor extent, Antwerp is similar because of its port. In this respect, Ghent is nothing more than a provincial capital.

In this paper, we explore the sources of this anti-urbanism, which are to be sought in the geographical dimension of the class struggle in Belgium, and elaborate on the electoral and socio-political consequences of it. In this second part of the paper we will dwell on the geography of the last parliamentary elections and the reasons why, against all antiurban feelings, urban policies should be put higher on the Flemish political agenda.

\section{Class struggle at the origins of anti-urbanism in Flanders}

5 The origins of this anti-urban attitude can be traced back to the geography of the 19th century industrial revolution and its social consequences (Saey e.a., 1998) $)^{5}$. The revolution was first fully developed in Wallonia, where it gave rise to the Walloon industrial axis related to coal mining. Although the geographical outcome of the industrialisation process was more regional than urban, it became clear how industrialisation and the spatial concentration of workers was accompanied by secularisation and the growth of the socialist labour movement.

Industrialisation and urbanisation in Flanders came much later - at least if we leave aside the textile industry, where home-working rather than large manufactures predominated until well into the 19th century ${ }^{6}$. In the meantime, the bourgeoisie and the Church had seen the danger coming and new resources were deployed to counteract it. At the political level, the papal encyclical letter Rerum Novarum (1891) was probably the most important measure, since it opened the way to the Church for counteracting the socialist labour movement with its own catholic labour organisations (Joye \& Lewin, 1967; Gerard, 1998). This strategy is at the origin of the Belgian pillarisation or compartmentalisation of 
society into a Catholic and a Socialist "pillar". Catholic workers are not only seen as workers, but also as members of the Catholic community and incorporated in a series of Catholic institutions and associations that can be mobilised each time the interests of the Catholic pillar came under threat (the most successful mobilisation in Belgian history concerned Catholic education). However, material life and mentality have been equally shaped by the efforts of the Catholics to limit the spatial concentration of workers in the large cities. Two types of interrelated measures were crucial in this respect: on the one hand, the increase of the mobility of the workers, on the other hand the promotion of home-ownership outside the cities. In sharp contrast with the socialist ideals, the Catholic strategies implied individual values to be ranked above collective values, the family above the working class and the home above the city.

In 1869 , cheap railway season tickets for workers were introduced. Although railway commuting was not to develop significantly until the end of the 19th century, this measure was illustrative of class relationships at the time. Workers could earn higher wages in the city than working the land, without losing it all in transport costs or more expensive urban housing. Moreover, they could produce some vegetables and raise small stock to complement their wage income. Their concentration in the poor, unhygienic and politically dangerous 19 th century city was counteracted ${ }^{7}$. But from the employers' point of view, the dispersal of the workers in the villages hindered their becoming aware of common workers' interests and kept them under control of the Church and local dignitaries. Even more, the latter continued to profit from rents paid for land. The possibilities offered by self-sufficiency in the countryside proved to be a kind of unemployment insurance for which the employers didn't have to pay. Even more, it was a chance for them to lower the wages, since the purchase power of the workers did not have to include the price of these self-produced means of existence. As a result of the very dense railway network (including many branch lines from 1885 onwards), the spatial effect of this measure should not be underestimated (Van der Haegen, 1984). It forms the basis for the relatively very large commuter zones around Belgium's large cities (Brussels in particular, where the size of the zone is almost comparable to that of London) ${ }^{8}$.

The first housing legislation of 1889 followed the workers' uprisings of 1886 (kept fairly successfully under control in Flanders) (Smets, 1977). Here too, the Catholics used a spatial strategy to fight out the class struggle. The law encouraged workers to acquire property. In owning their own homes, they would empathise with the interests of the propertied class and, in addition, they would now also be bound to pay off their mortgage, which should make them think twice about going on strike. However, property acquisition would also put family life in the spotlight and raise the individual interests of every family above the collective interests of the workers. Finally, it would also draw workers away from the urban working class areas - particularly the better paid and better educated workers who should be able to play a leading role in the workers' movement - and anchor them down in neighbourhoods on the edge of town, where they could still afford land prices.

9 The garden suburb idea, which would define social housing construction in Belgium following its inception in 1919, must be seen within the context of this past, even if socialist players are the driving forces in this case. The garden suburbs have to be located in the countryside, but closely connected to the city, so as to alleviate the evils of the city and support the progress of industrialisation at the same time. Socialists adopted the idea of taking the workers out of the city, since it was the most evident way to improve their 
living conditions. However, contrary to the Catholics, who banned every collective service from the garden cities, except the church and the catholic primary school, the Socialists did see these services as a way to strengthen their movement (Mougenot, 1988). Catholics, on the other hand, were to place further stress on the individual home and continue to encourage an exodus from the city, with the most significant housing measures since the formation of the Société Nationale des Habitations à Bon Marché Nationale Maatschappij voor Goedkope Woningen (National Social Housing Association) (Goossens, 1983). First came the Moyersoens law in 1922, which provided a subsidy for the acquisition of property, then the formation of the Housing Fund of the Ligue des Familles Nombreuses - Bond der Kroostrijke Gezinnen (Union for Large Families) in 1928, which provided cheap mortgages for large families, followed by the formation of the Sociéte Nationale de la Petite Propriété Terrienne - Nationale Maatschappij voor Kleine Landeigen-dommen (National Society for Small Landowners) in 1935, whose intention was to promote a return to the land for workers who found themselves out of work and to give them an incentive to garden and cultivate on a small scale (it thus repeated resorting to self-sufficiency as a cheap alternative to unemployment benefits in the new times of crisis) and, finally, the building premium provided by the De Taeye law in 1948, which fixed the present-day appearance of the Flemish residential landscape, with either strip building along the roads or residential estates scattered in the countryside. The premium helped individual households to become owner-occupiers by building their own house. More than one-third of all post-war new housing construction was co-financed by the premium and the large majority of it took place in the countryside, because of the cheaper land prices. Fordist economic growth and suburbanisation, the spatial embodiment of the consumer society upon which this growth is founded, took care of the rest. Indeed, the increase of purchase power, full employment and the general spreading of credit supported access to owner-occupation outside the cities. This new residential environment forced the households to enter in a consumption spiral of durable consumption goods, chiefly the car and home appliances. The resulting continuous expansion of the sales of these goods promoted economic growth.

The legendary brick in the Belgian stomach (by which is meant that the dream of every Belgian is to build his own house) is therefore a chiefly Flemish (and Brussels) brick. It has little to do with our attitude or genes, but was served up to the population over a 120year period, as a solution to social struggle in the context of unequal regional development and the pillarisation of Belgian society. The complete lack of effective spatial planning until the late 1970s provided the required space, while the Keynesian zeal to create infrastructures, associated with the local politicians' inclination to identify a rising municipal population with increased welfare, provided the (expensive) conditions for the emergence of a primarily Flemish housing estate mentality, which demotes the city into a place of work. Even more, the economic expansion laws of 1959 and 1970 added industrial estates to the housing ones. Everywhere, but again more in Flanders than Wallonia, industrial parks were created to promote employment. They nurtured the claims for work in one's own region and, at least in the mentality of the non-urban population, nearly transformed the cities into redundant places. 


\section{The Christian political hegemony}

11 As is evident from the analysis above, the traditional predominance of Christians in Flanders - in contrast to the predominance of socialism along the Walloon industrial axis - is certainly the result of the industrial revolution, the Church and the bourgeoisie having the time to take those measures which would nip socialism in the bud (Vandermotten e.a., 1990).

12 Socialism and liberalism - which sprouted from the civil and industrial revolutions - only made a breakthrough where the Christian strategy was not fulfilled or came too late (figure 1). The regions where textile or small-scale rural industry - sugar factories, breweries, distilleries - led to the emergence of small towns, are usually bastions of liberalism. These industries, local and family-based in nature, produced a bourgeoisie who rose up against Catholic conservatism and which succeeded in bringing about local, relatively sustainable hegemony. This is the case in the electoral cantons of Landen and Tienen and in cities such as Ghent, Ronse, Oudenaarde, Lokeren and Ninove. However, in all those places where industrialisation has eroded the traditional ideological structures, socialism also makes its mark. More so than liberalism, it is an urban phenomenon: this can be seen in Ostend, Ghent and particularly along the Antwerp-Brussels axis. The Hageland and Haspengouw, between Leuven and Sint-Truiden, are the exceptions, where "commuter socialism" is evident, upheld by the local working population which reports on a daily or weekly basis to a more militant working environment in Brussels, Antwerp or the mines of Liège and later also Limburg.

Figure 1. The Christian political hegemony in Flanders 1921-1985.

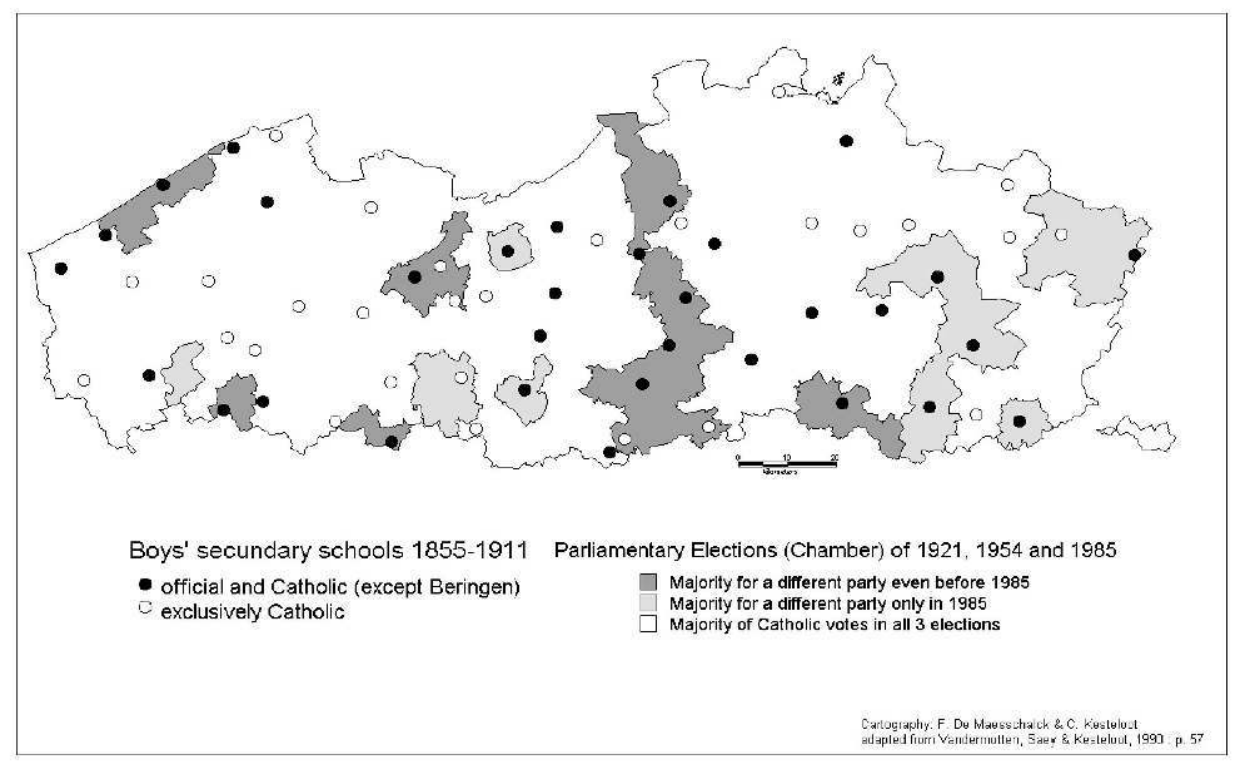

13 Everywhere else, the Christian political family dominates. Paradoxically, even the Limburg mining basin remains chiefly Catholic. Through paternalistic measures and the development of garden suburbs and facilities, the mine owners built up social and ideological control over the workers, founded on their Catholic background. The commuters from the Hageland escaped this tight territorial control and were therefore 
more militant (De Rijck e.a., 2000). The Flemish post-World War II CVP (Christian People's Party) landscape is therefore supported by sturdy geopolitical structures which were surprisingly reinforced by educational structures dating from before the First World War and local political practice.

The Catholic hegemony in secondary education, dating from before the Belgian independence, could not be broken by state education in large part of both Flanders provinces (west of the Antwerp-Brussels axis) and in the Antwerp and Limburg Campine (north east of the Region) and these areas are still the political strongholds of the Christian Party at the end of the $20^{\text {th }}$ century. Only a few shifts took place after the Second World War. Aside from the power struggles between Socialists and Liberals in a few cantons, the CVP only lost significant ground in Limburg, to the SP (Socialist Party) (where the local leader was the future Nato General Secretary Willy Claes) and to the VU (Volksunie - Flemish nationalist party) (their local leader took his electors with him when he crossed over to the VLD (Liberal Party)). Fundamentally, these changes have to do with the Fordist international investments in Limburg that destroyed the economic hegemony of the mining world (Swyngedouw, 1990). The closure of the mines in the late 1980s and early 1990s have reinforced this tendency.

\section{The shifts of the 1999 parliamentary elections}

15 Although there have been more severe changes in terms of votes in earlier periods, the federal and regional elections of 13 June 1999 brought about the most considerable spatial shift in Flanders (Vandermotten e.a., 2001), both in terms of results and in the ensuing coalition. The latest municipal election did confirm this shift. In order to measure its extent, we compare the geography of the election results with the traditional geopolitical fault lines in Flanders9. After all, these geopolitical structures expose undercurrents that are decisive in the success and decline of the major political families. Not every place within a region experiences the influence of these undercurrents with the same intensity, but every local party stronghold or the dominant role of one party in a particular area reminds us of the historical facts which have formed the Flemish political arena.

The shift is first documented by a synoptical analysis of the votes with a principal correspondence analysis. This multivariate technique can visualise relationships in a frequency table. More specifically, correspondence analysis can visualise interdependencies of rows and columns in a scatter plot.

In this analysis, the rows represent the electoral cantons and the columns the political parties. Each cell represents the number of votes for that party in the canton involved. Thus, the rows show how the votes of one canton are allotted to the different parties. The columns show the spatial distribution of the votes for one party. The correspondence analysis leads to a visualisation of the relations between parties and cantons, by placing both the rows and the columns on common planes. The centre of these planes represents the average situation. In other words, a canton having the same distribution of votes as the whole region, would be in the centre. Similarly, a party having exactly the same percentage of votes in each canton, would be projected in the centre of the plane. The more a party or a canton diverges from the equipartition situation, the further it will be placed from the centre on the plane. Parties with a similar electoral geography will be placed close together in the plane. Equally, electoral cantons with a similar distribution of votes over the parties, will be close to each other. Finally, parties and cantons situated in 
the same direction from the centre are linked by a common overrepresentation (the party collects relatively more votes in this canton and the canton votes relatively more for that party than for the others). In order to avoid any misinterpretation, one also has to verify if the concerned parties and cantons are well represented in the planes. Indeed, it is impossible to represent all the deviations in canton and party profiles from the equipartition situation in one single bi-dimensional plane. The successive dimensions embody the largest possible share of the total deviations (called inertia), but when only two of them are selected to span a plane on which parties and cantons are projected, some parties and cantons will be poorly represented. In that case it is impossible to say anything significant about their position in that plane. The quality of this representation can be measured for each element by means of the square cosines of the angles between both axes and the vector defined by the position of the element in the multidimensional space describing all the deviations. When the sum of both squared cosines is one, it means that the vector lies perfectly on the visualised surface, and thus is entirely represented. When the sum is zero, the vector lies perpendicular to the visualised surface, and nothing can be said about the distance and direction of the element concerned. The closer this value to one, the more the point is representative, and more meaningful the interpretations extracted from it (Greenacre \& Blasius, 1994).

When we look at the results, the total inertia can be described in six dimensions, or six orthogonal axes. It turns out that the first three axes already describe $83.5 \%$ of the deviations vis-à-vis to the expected row- and column profiles (table 1). If we only consider these three axes, the VU-ID ${ }^{10}$ and Agalev (the Greens) are not very well represented. The former has clearly its own electoral geography, related to the strongholds of some party leaders. The latter has a weaker idiosyncratic pattern. A close examination of the data reveals a strong positive deviation in the canton of Leuven, explained by the weight of the university on the socio-economic structure of the population. However, the Greens are equally well represented by the first two axes. The three traditional parties and the extreme right (Vlaams Blok) are well represented by the first three axes. Therefore, we examine the results in two planes: the plane spanned by the first and the second axes and the one spanned by the first and the third axes.

Table 1. Principal correspondence analysis of the Parliamentary elections 1999: the squared cosines of the parties for the different dimensions.

\begin{tabular}{lcccccc} 
& Dimension & Dimension & Dimension & Dimension & Dimension & Dimension \\
\hline \multicolumn{1}{c}{} & 1 & 2 & 3 & 4 & 5 & 6 \\
\hline \% of total & & & & & & \\
\hline inertia & 43,1 & 24,7 & 15,7 & 9,2 & 5,9 & 1,5 \\
\hline & & & & & & \\
\hline CVP99 & 0,711 & 0,147 & 0,063 & 0,078 & 0,000 & 0,000 \\
\hline SP99 & 0,023 & 0,874 & 0,096 & 0,006 & 0,000 & 0,000 \\
\hline VLD99 & 0,051 & 0,026 & 0,919 & 0,000 & 0,005 & 0,000 \\
\hline VLBLOK99 & 0,878 & 0,017 & 0,015 & 0,036 & 0,053 & 0,001 \\
\hline AGALEV99 & 0,373 & 0,110 & 0,002 & 0,006 & 0,480 & 0,028 \\
\hline VUID99 & 0,018 & 0,266 & 0,047 & 0,633 & 0,037 & 0,000 \\
\hline OTHERS99 & 0,606 & 0,001 & 0,005 & 0,000 & 0,108 & 0,281 \\
\hline
\end{tabular}

20 To distinguish between urban and non-urban cantons, and to avoid overloading the figures, we introduced a simple measure for urbanism. Population density seems to be the 
most logical criterion, though the differences in size of the electoral cantons can disturb the picture. However, when an urban canton contains non-urban zones (or vice versa), a part of the election results in this canton can be said to be non-urban. Therefore, we can justify this approach. We chose a threshold of 500 inhabitants $/ \mathrm{km}^{2}$, and all the electoral cantons that didn't reach this threshold are indicated on the figures with "P". This results in 25 cantons being classified as urban ${ }^{11}$, which are identified by their names. Not every canton is equally well represented in each of the visualised subspaces, but the major part of them is well represented on the first three axes.

21 Figure 2 visualises the first two dimensions. The first dimension clearly separates urban (and industrial) cantons from non-urban cantons. The profile deviations of the urban cantons correspond with the electoral geography of the Vlaams Blok, and, although they are not very well represented on the graph, to a lesser extent Agalev and the small parties. The right upper quadrant also contains a few rich, suburban cantons around Antwerp: Kapellen, Kontich, and Duffel. The non-urban cantons in this area are also less densely populated cantons in the Antwerp periphery. Thus, the upper part of the graph illustrates the Vlaams Blok strongholds, which are mainly urban and suburban, and the fact that the Greens are the only important party that confronts extreme right in the same cantons. In contrast, the Christian Democrats are over-represented in the nonurban areas, confirming the geopolitical positioning of the party. The urban cantons in the south of the province of West-Flanders form a remarkable exception: Kortrijk, Menen, Harelbeke, Izegem and Roeselare where endogenous economic development has taken place, protected from the influences of Belgian high finance and, subsequently, from foreign investment. This development is borne along by Christian ownership, which sprouted from the small and medium-sized enterprises that have their roots in former flax cultivation. The region, which boasts of being the "Texas of Flanders", remained faithful to its ideological roots. 
Figure 2. Principal correspondence analysis of the Parliamentary elections 1999: plot of parties and electoral cantons on the first and the second axis.

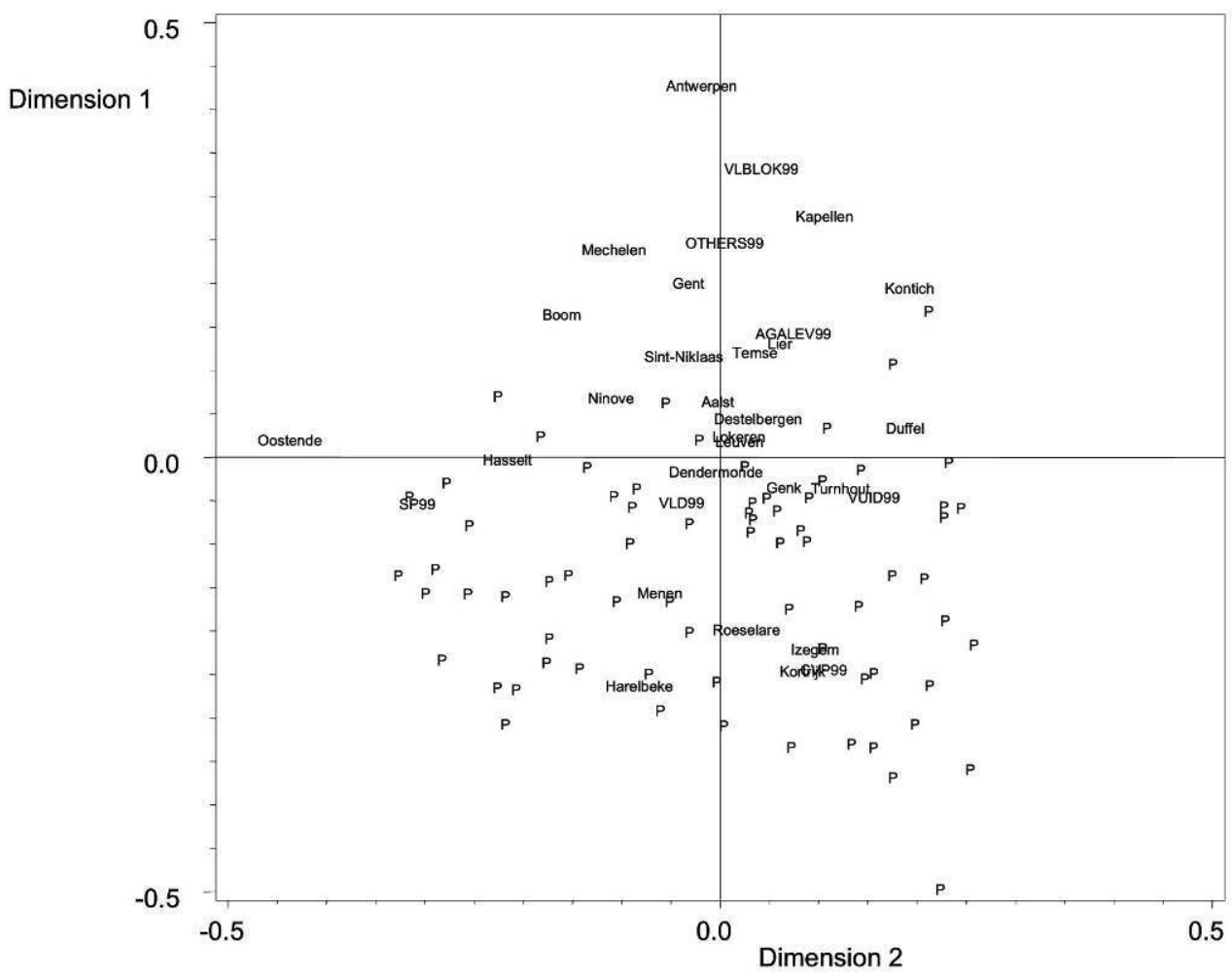

The second dimension contrasts the socialist-oriented cantons on the left side with the other parties on the right (except the Liberals (VLD $)^{12}$ not representative on this plane). The previously mentioned traditional urban socialist bastions are all in the upper left quadrant. The higher their score on the first dimension, the more they have been taken over by the Vlaams Blok and Agalev. The Socialists' position reveals they are not anymore the urban party par excellence. Indeed, the first axis separates the urban areas from the other, and not the second. After all, quite some non-urban cantons are situated in the lower left quadrant of the figure. Only Ostend and Hasselt (Limburg) appear as socialist urban strongholds, and both are related to the presence of strong electoral candidates. The electoral geography of the Liberals is revealed by the third dimension (figure 3). The vertical axis is again the first dimension, contrasting the urban and non-urban cantons. 
Figure 3. Principal correspondence analysis of the Parliamentary elections 1999: plot of parties and electoral cantons on the first and the third axis.

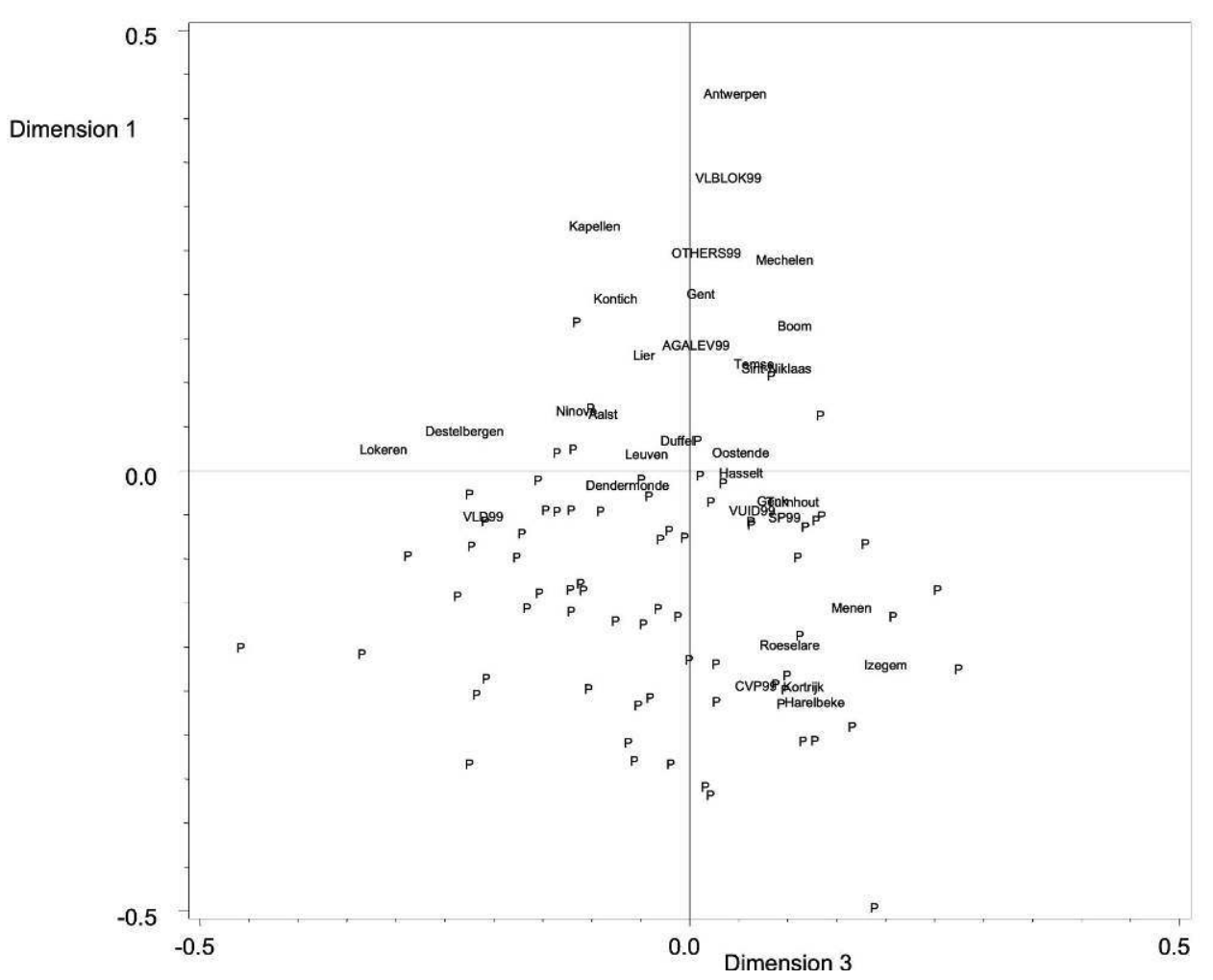
of SP, Agalev and VU-ID are not significant on this plane). Thus, compared to the others,
the Liberals are the closest to equipartition. Obviously, a large majority of the non-urban cantons, small cities and suburban cantons (Destelbergen is the only suburban canton of Ghent classified as urban) are those where the Liberals are over-represented. The upper left quadrant displays the cantons where the VLD is challenged by the Vlaams Blok and/ or Agalev. In fact, all the suburban cantons around Antwerp are located in it. But on this level, as is the case with the Socialists in Hasselt and Ostend, we should also consider the role of candidates, more intensive campaigns and -connected with these factors- electoral discourses restricted to this area.

In order to visualise the shifts over time, we made a similar analysis with the results of the parliamentary elections of 1987, and calculated the positions of the parties in the 1999 elections on these planes. The structure of the squared cosines is less clear in 1987 (table 2). In other words, the particularities of the electoral geography of each party cover several independent dimensions. Nevertheless, the first axis expresses the same geographical polarisation as in 1999, even if the Christian Democrats also have their own dimension. The second part of the table shows how well the geographical electoral profile of the parties fit into the 1987 situation. VU-ID, and to a lesser extent Agalev and the others, experienced a rather important shift, since their inertia is not very well described by the six dimensions of the 1987 results. However, more shifts are expressed by swaps between dimensions. Thus, both the Christian Democrats and the Liberals lost their distinctive dimension and are best represented by the first, most general dimension. Moreover, the much lower cosine of the 1999 results of the Vlaams Blok on this dimension points to a less unique geographical profile.

The VLD appears in the lower left quadrant, quite close to the graph centre (the positions (itmension points to a less unique geographical profile.

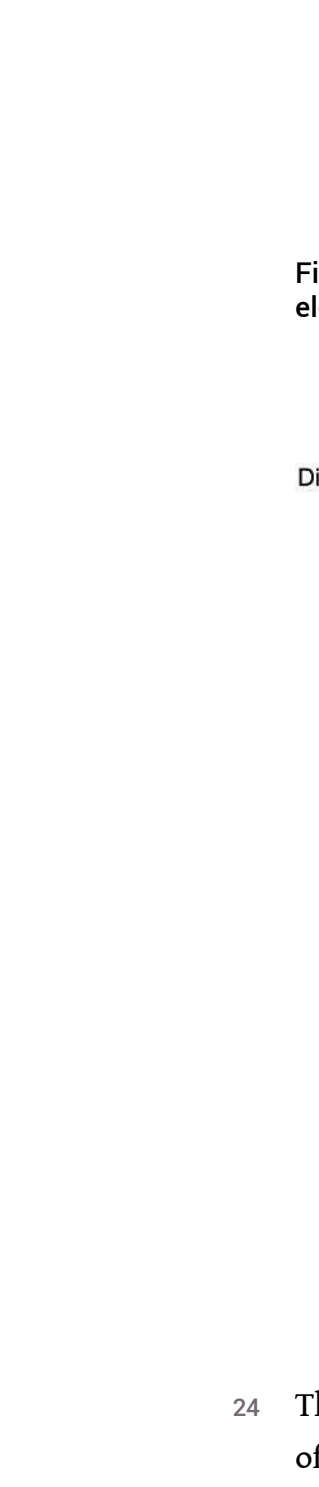


Table 2. Principal correspondence analysis of the Parliamentary elections 1987: the squared cosines of the parties for the different dimensions and position of the parties in the 1999 elections.

\begin{tabular}{|c|c|c|c|c|c|c|c|}
\hline & Dimension & Dimension & Dimension & Dimension & Dimension & Dimension & $\%$ of row \\
\hline & 1 & 2 & 3 & 4 & 5 & 6 & inertia \\
\hline \multicolumn{8}{|l|}{$\%$ of total } \\
\hline inertia & 37,3 & 27,6 & 16,5 & 14,1 & 2,4 & 2,2 & \\
\hline CVP87 & 0,457 & 0,051 & 0,466 & 0,011 & 0,010 & 0,004 & 100 \\
\hline SP87 & 0,110 & 0,210 & 0,162 & 0,518 & 0,000 & 0,000 & 100 \\
\hline PVV87 & 0,124 & 0,445 & 0,091 & 0,339 & 0,000 & 0,000 & 100 \\
\hline VLBLOK87 & 0,910 & 0,000 & 0,026 & 0,039 & 0,003 & 0,021 & 100 \\
\hline AGALEV87 & 0,348 & 0,005 & 0,298 & 0,008 & 0,299 & 0,042 & 100 \\
\hline VU87 & 0,000 & 0,795 & 0,189 & 0,016 & 0,000 & 0,000 & 100 \\
\hline OTHERS87 & 0,595 & 0,001 & 0,029 & 0,032 & 0,097 & 0,247 & 100 \\
\hline CVP99 & 0,584 & 0,073 & 0,089 & 0,019 & 0,017 & 0,000 & 78,3 \\
\hline SP99 & 0,020 & 0,075 & 0,198 & 0,362 & 0,013 & 0,000 & 66,7 \\
\hline VLD99 & 0,314 & 0,043 & 0,058 & 0,226 & 0,019 & 0,039 & 70,0 \\
\hline VLBLOK99 & 0,688 & 0,018 & 0,027 & 0,019 & 0,004 & 0,002 & 75,7 \\
\hline AGALEV99 & 0,063 & 0,029 & 0,160 & 0,020 & 0,176 & 0,147 & 59,4 \\
\hline VUID99 & 0,113 & 0,202 & 0,040 & 0,009 & 0,003 & 0,002 & 36,8 \\
\hline OTHERS99 & 0,341 & 0,001 & 0,001 & 0,009 & 0,004 & 0,192 & 54,8 \\
\hline
\end{tabular}

The plot of the first and the fourth axes (figure 4) yields a more powerful illustration of these shifts. The latter was chosen because it places the strong socialist-oriented cantons on the left of the figure (and partially opposes them to the strong liberal-oriented cantons). This has the advantage of comparability with figure 2, where the socialistoriented cantons were also positioned on the left side of the figure. Since the added share of the total inertia of both dimensions only slightly exceeds the $50 \%$, interpretation must be given with caution. Moreover, Agalev, VU and the others are ignored because their deviations are not well reflected in this plane. 
Figure 4. Principal correspondence analysis of the Parliamentary elections 1987: plot of parties and electoral cantons on the first and the fourth axis and position of the parties in the 1999 elections.

1.0

Dimension 1

0.5

1

0.0

$-0.5$

Compared to the 1999 elections, the dichotomy between urban and non-urban cantons is weaker. Most non-urban cantons are still in the lower half of the graph, but only Antwerp, its suburbs and Mechelen are on the positive side. This position is obviously related with a strong overrepresentation of extreme right votes. The expansion of the Vlaams Blok outside its Antwerp bastion started on the first "Black Sunday" in 1991. Furthermore, the non-urban cantons are more concentrated in the lower right quadrant, related to Christian Democrat and/or Liberal over-representation. The Socialists appear as a much more urban party than in 1999.

The shifts between 1987 and 1999 are indicated by arrows. Although the positions are not perfectly represented, three types of changes are observed. Clearly, the CVP and the SP move away from the centre, indicating they diverge more than in 1987 from an equal strength in all cantons. The Liberals are moving towards the former position of the Christian Democrats. In other words, they gradually take over the positions held by the CVP. The transfer to liberalism undoubtedly reflects the conscientious centrism of the large political families. They are all fishing for the votes of the same middle classes (that became as a matter of fact the largest social group in society) and therefore abandoning all defence of the ideology and social model which formed the basis for their movement, referring to the classical socio-political fault lines in our society (Vanlaer, 1984). This shift to the centre is related to what Galbraith terms the "politics of contentment" (Taylor, 2000). For the majority of the voters, good life continues after the crisis, and they don't need any more a part of the State's social facilities, which were a component of the socialdemocratic consensus. Understanding this, the political parties became pure representation parties. They abandoned to a considerable extent their original ideology and all lean on the same (neo-liberal) project. All traditional parties propagate these "new 
politics" of globalisation. Precisely these "new politics" and their effects, which are most striking in the cities, are questioned by Agalev and the Vlaams Blok.

In addition, the assignment of election campaigns to the media and to marketing consultancies has meant that the political messages of the large parties have become highly homogenised. The switch from one political family to another is therefore very difficult to interpret as a political U-turn. It is much more a reflection of the request to change teams (the promised "change") in order to continue pursuing more or less the same policy.

Finally, and most obvious, the Vlaams Blok displays the most important shift towards the centre, reflecting its growing success across the whole of Flanders. The progress of extreme-right has been larger in the periphery than in the urban areas since 1991 (figure 5). In addition, the absolute growth in percentage has been greater in the periphery than in the urban areas since 1995 (De Maesschalck, 2000).

Figure 5. The ratio between the percentage of votes for the Vlaams Blok in 1995 and 1991.

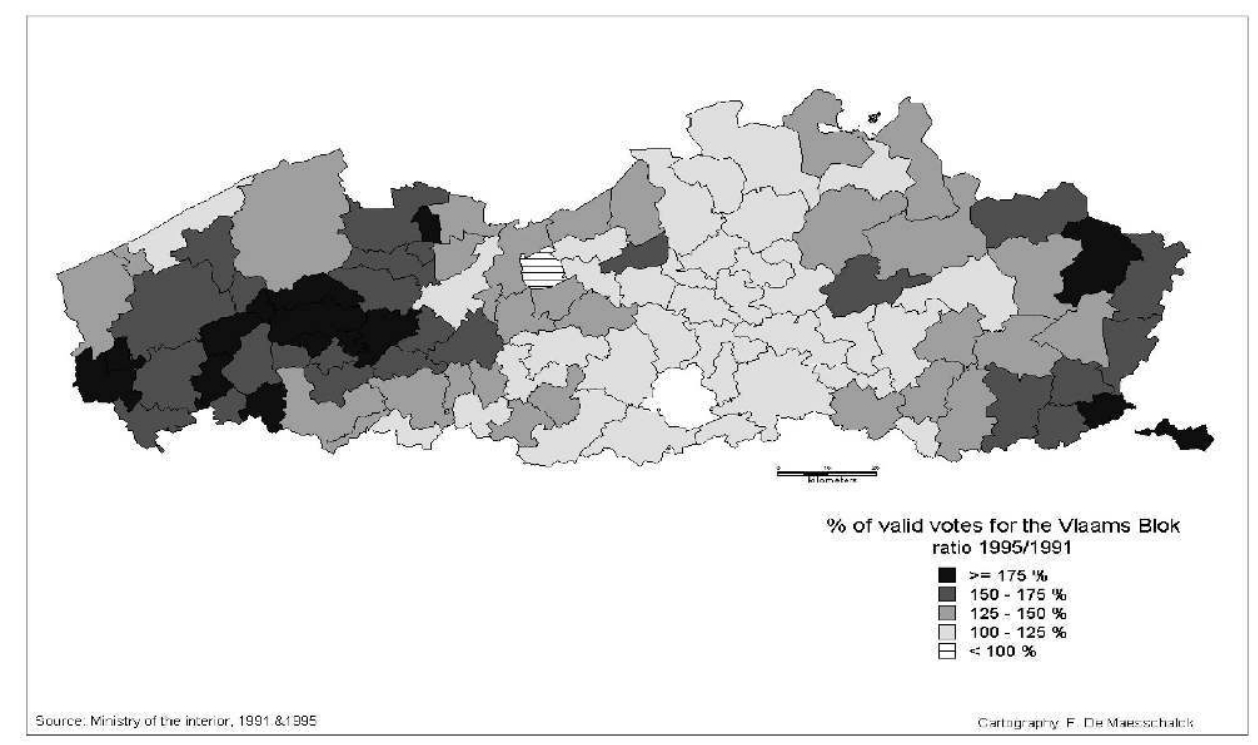

This expansion of the Vlaams Blok from Antwerp is organised along three lines, each embodying a precise form of racism (Kesteloot \& De Decker, 1992). Firstly, the party targets the (relatively scarce) voters in deprived areas, who are usually shrouded in insecurity themselves, by picking out the "migrants"13 as being responsible for their situation (despair racism). Therefore, the Blok focuses on the working class areas of the large cities and the smaller industrial cities, where immigrants share the neighbourhoods with the Belgian working class, victim of deindustrialisation, the economic crisis and loss of social networks. Clearly, they capture socialist votes in this area. The Blok also looks for voters among the middle classes by creating for them the illusion that it has a solution to the "migrant problem" which will not threaten either the position or the peace of mind of the middle classes (distancing racism - even if one is not directly confronted with the presence of immigrants, the racist views of the Vlaams Blok are approved, since they promise the use of the city without being troubled by the differences, the inequalities and insecurity generated by the urban social injustice). CVP and even more VLD are losing in this case (Swyngedouw \& Beerten, 1999). Finally, the two themes are linked together in 
pure electoral racism, which strengthens the two previous types, even in places where such racism has no focus (perfectly translated by the slogans "Eigen volk eerst" - Own people first - and "Baas in eigen land" - Boss in one's own country.

The multivariate analysis of the electoral data reveals three main changes compared to Flanders' traditional geopolitical structure: a loss of power of the Christian Democrats, mainly in favour of the Liberals; a change in the geographical specificity of the Socialists: they lose ground in the cities and maintain only a few strongholds where individual candidates make the difference; a dramatic expansion of the Vlaams Blok over the whole Flemish Region (not to mention their attempt to conquer the majority among the Flemish minority in Brussels). An analysis of the electoral maps of the 1999 elections sheds more light on these shifts and reveals more complex relations between the parties and antiurbanism.

A look at the spatial pattern of the dominant parties in each canton confirms the substitution of the Liberals for the Christian Democrats (figure 6). The CVP only holds its ground in the Antwerp Campine, North Limburg, West Flanders and the Meetjesland (the northwest of East Flanders). These areas correspond fairly well to the areas where the education hegemony of the Catholics was maintained through the 19th century (figure 1). Nevertheless, these are economically speaking peripheral regions with low population densities. In the central area, that some are keen to refer to as the "Flemish Diamond" (the Antwerp-Ghent-Brussels-Leuven quadrangle), the CVP only offers resistance in those cantons which are the least influenced by regional economic development, specifically the north of the Waasland and the Pajottenland, south-west of Brussels. The only noteworthy exception to this marginalisation of the CVP is the area around Kortrijk already described in the correspondence analysis.

Figure 6. The political map of 1999 (Parliament elections).

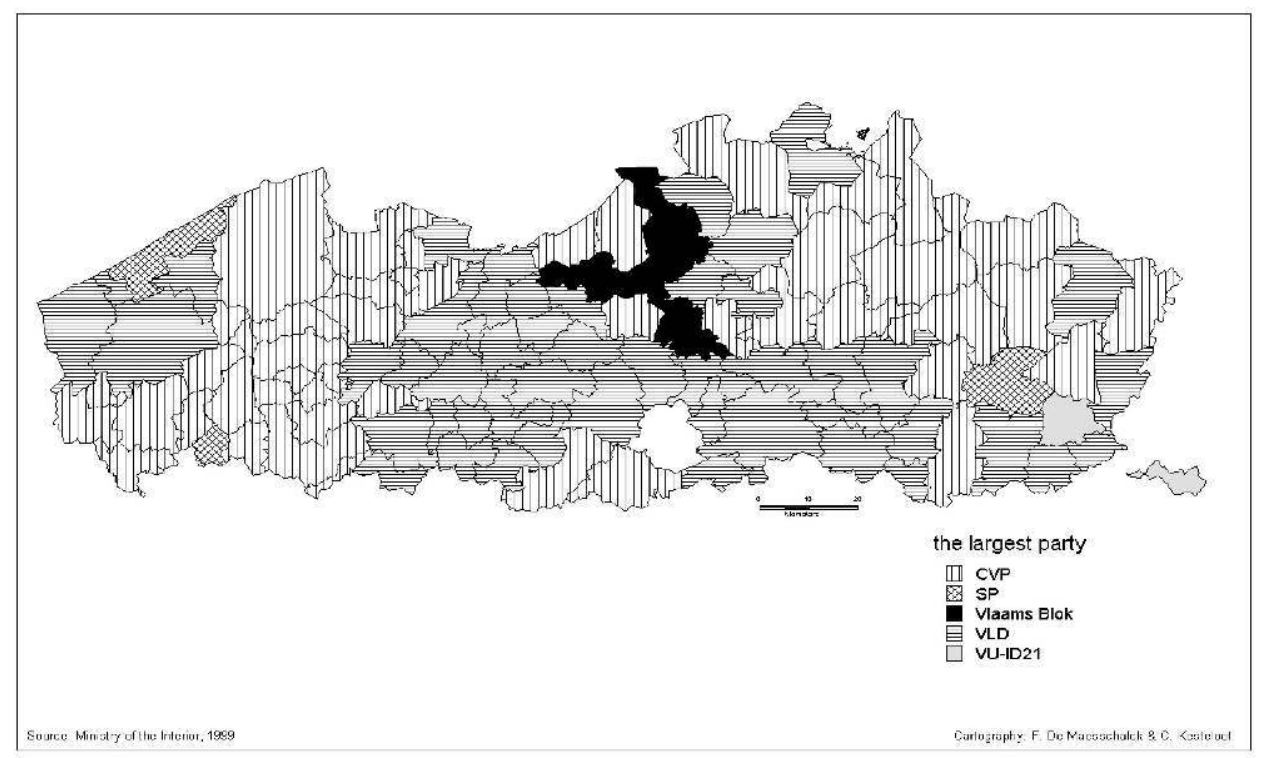

The VLD has become the dominant party in the vast majority of the other cantons. No historical structures can be found which indicate any predestination for that area forming a wide swathe from Ghent to South Limburg - to switch from catholicism to liberalism. This is, however, the zone with the highest population density, with the most 
intense development of Flemish prosperity. This is expressed in the dominant residential form, housing estates that are neither rural nor urban and village places that have been transformed into financial centres where every large bank has a branch. Surprisingly enough, this way of life and this landscape are much more likely to have been created by the aforementioned Christian politics than by liberal progressive thinking.

From this point of view, the crumbling of the Christian Democrats does not represent the major shift in Flemish geopolitics. By contrast, the collapse of the Socialists is much more spectacular. Urban socialism has lost all its allure. The red zone from Antwerp to Brussels has turned brown. Ghent fell into the hands of the Liberals and has also witnessed a worrying surge of the extreme right Vlaams Blok. Except where they have held on thanks to accidental personal success (Ostend and Limburg), the socialist cantons are no longer the most industrialised nor the most urban (with the exception of the small town of Wervik in south West-Flanders) (figure 7). On the contrary, in 1999 the geography of socialism in Flanders looks very much like that of the CVP: between them, they share the remainder of the periphery in West Flanders and Limburg.

Figure 7. The votes for the SP (Socialists) in 1999 Parliament elections.

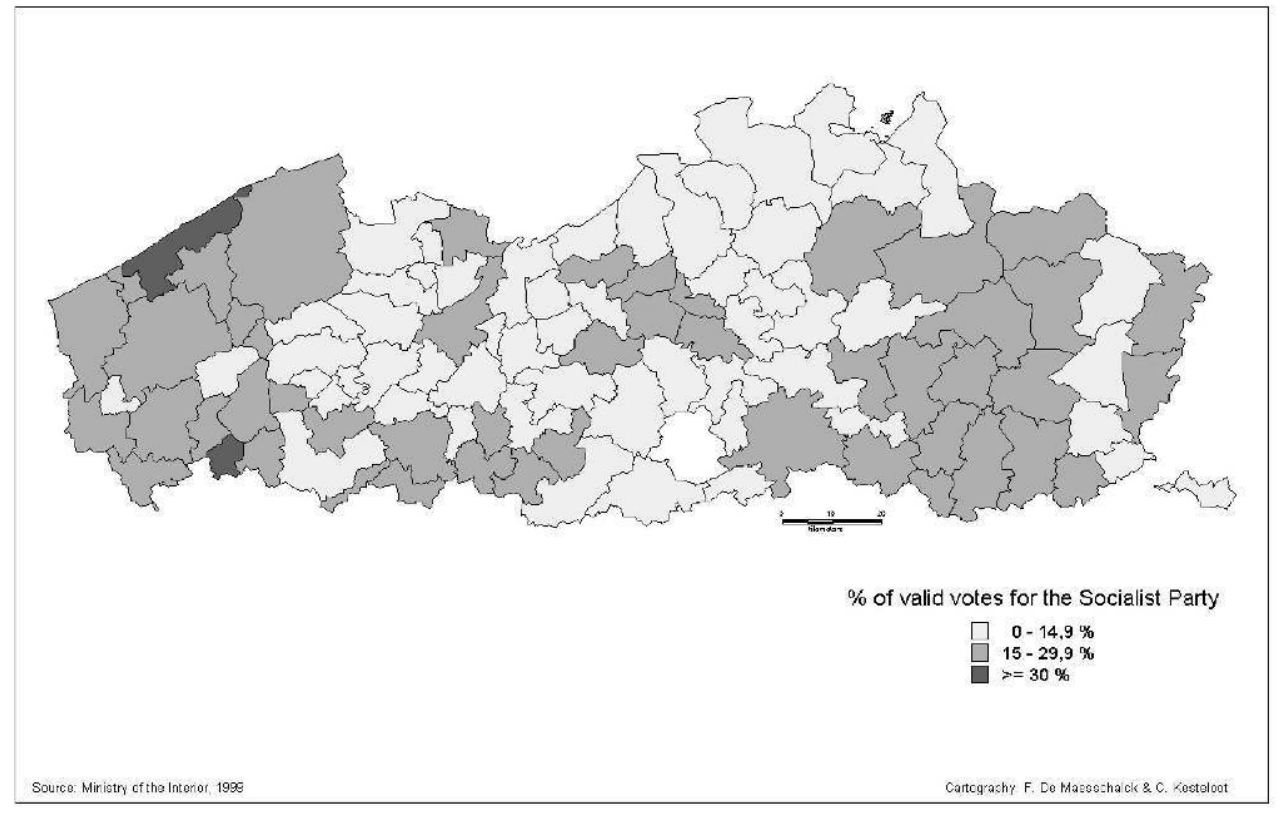

Today, the old socialist and liberal bridgeheads are controlled by the Vlaams Blok and Agalev (Figures 8 and 9). The Vlaams Blok regularly collects over 20 percent of the votes from Antwerp to Mechelen. In Ghent and along this axis, it obtains over 15 percent, benefiting from the tensions surrounding the presence of immigrant workers in Lokeren (a small textile town between Antwerp and Ghent), Beringen (a former coal mine in Limburg) and also in Ronse (another textile town along the southwest border; Moroccans from Brussels have settled in Ronse relatively recently in an effort to accelerate their integration and social promotion by moving out of concentration zones). 
Figure 8. The votes for the Vlaams Blok (extreme right) in 1999 Parliament elections.

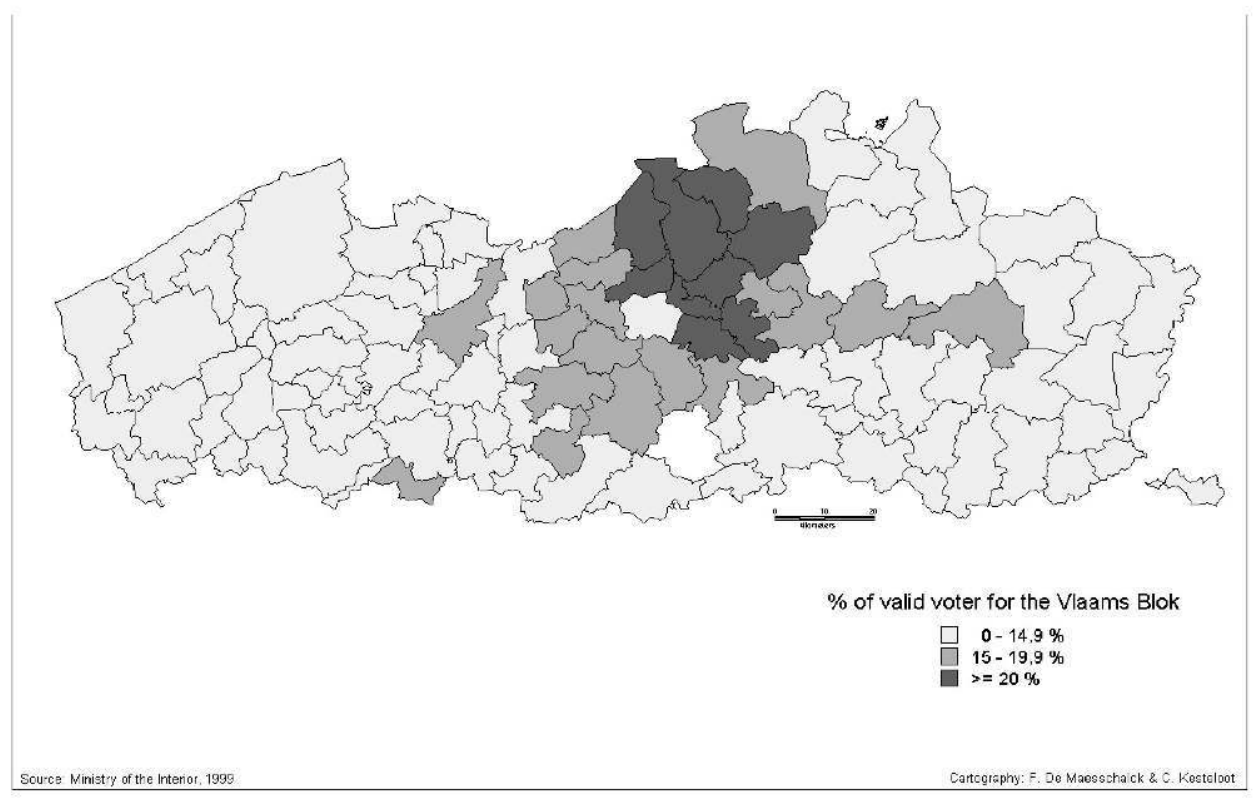

Figure 9. The votes for Agalev (the Greens) in 1999 Parliament elections.

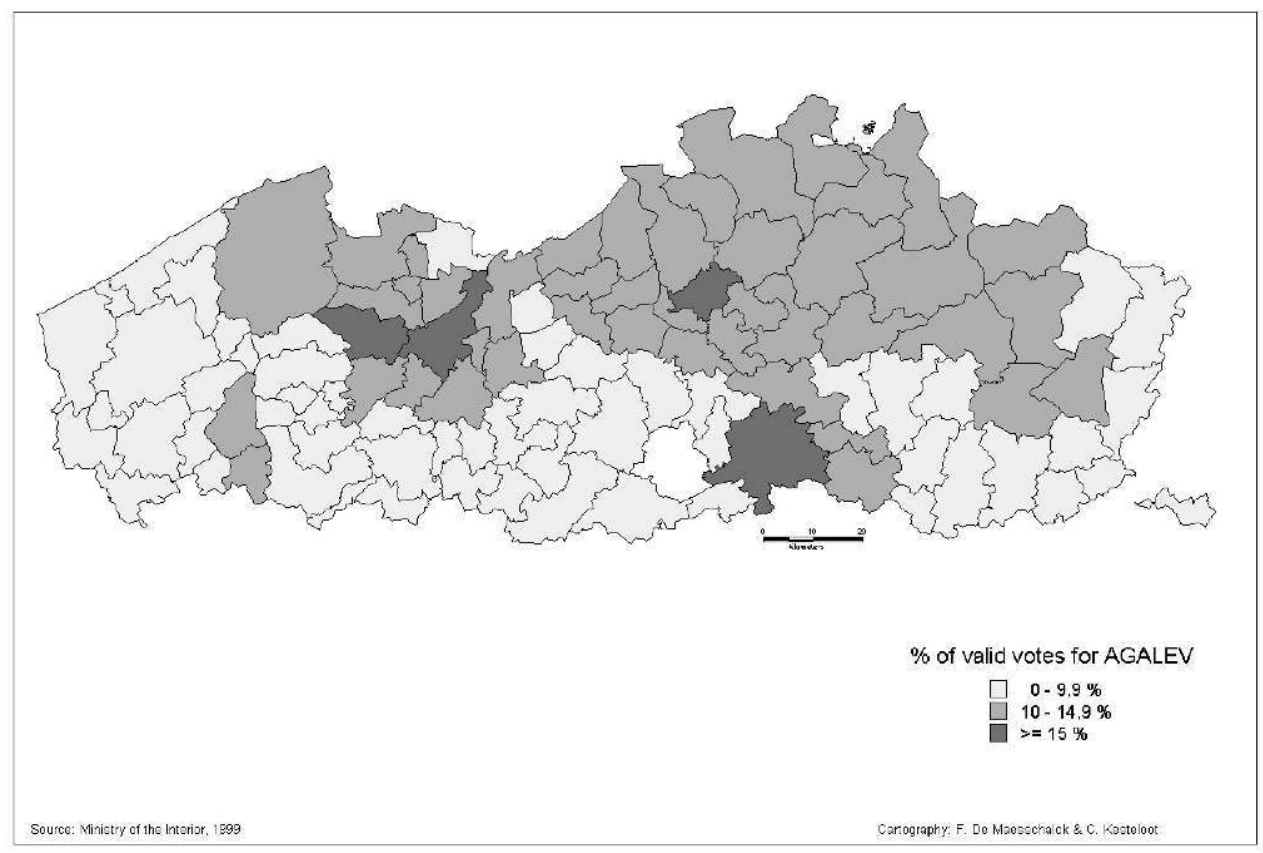

Nowhere in Flanders is Agalev the dominant party, but it has strongholds in the entire province of Antwerp and in the cities of Ghent and Leuven from where the Greens - in spite of the Vlaams Blok in Antwerp - are expanding their electoral base.

Although the largest relative increases of the extreme right votes are in the peripheral cantons, the Vlaams Blok appears to have an expansion strategy that follows the urban hierarchy and then spreads over the concerned suburbs. However, the Vlaams Blok is not an urban party. It in no way defends the interests of the cities and their inhabitants, who 
have suffered in recent decades from the consequences of the economic crisis and globalisation. The Vlaams Blok uses racism and repression - under the guise of security to tackle social exclusion in deprived districts, the problems associated with unemployment, poor housing and the lack of socialisation of young people. In this way, the problems are apparently ironed out by eliminating their victims from the towns and cities.

This argument makes the Vlaams Blok a Trojan horse in Flemish cities. After all, immigration, diversity and all the social and cultural input a city can attract, are regarded as a problem to which purification and homogenisation are the solutions. In th long term, such a view implies the destruction of urbanism. After all, towns and cities do only exist as a result of constant rejuvenation and diversity. They only have a future if they can continue to sustain themselves through immigration (see further).

On the other hand, the spatial analysis of the election results pushes the Flemish Greens to the fore as worthy successors to the previous century's Liberals and Socialists, who were incidentally together regarded as the political left until the inter-war period. The VLD has replaced the CVP as representative of the large Flemish anti-urban middle classes. For their part and no doubt because they exaggerated the centrism aspect, the Socialists also lost their links with the cities. But Agalev still has to realise - and make it clear to its electoral public - that it is the party that can pick up the threads of the long history of emancipation and progress taking place in the urban arena. The Socialist party is the only one that could join the Greens in this project, as far as it succeeds to recover its former electoral position.

41 The municipal elections of October 2000 have further underlined that the city turns to be the new political question in Flanders. Both the regressive effects of the anti-urban mentality and the danger of leaving the cities and their social problems to the Vlaams Blok are at stake. The Vlaams Blok has strengthened its position in the Flemish cities, even in Antwerp where it now reaches one third of the votes. Most political analysts were surprised by the strong results of extreme right in the Antwerp suburbs. It reveals that the process of distancing racism is not yet understood. This electoral choice reflects the preference for a repressive city rather than urban solidarity: in order to continue to use the inner city amenities in total safety these voters prefer a stronger police and a more stringent judicial apparatus against the urban youth, rather than a social and economic policy that attacks the roots of the urban malaise. As a matter of fact, the police in the inner city is chiefly paid by its poor inhabitants, while the alternative policy is necessarily financed at the federal or regional level... The (fragile) revival of the SP was more of a surprise and it could play a role in the setting up of a possible urban alliance against the extreme right danger. In order to regain power, the party plans a large-scale renewal project. For such a relining, one can make a double distinction, between social strategy on the one hand and political strategy on the other (Johnston, 1990). Concerning the first, the Socialists can try to regain the traditional workers' support, or try to extend their electorate to other classes. The SP chooses clearly for the second option, also because the workers and the small employees form a too small electoral basis. Concerning the second, the party has to choose between either the traditional issues, or a new political programme (like Labour invented "the Third Way" in Great Britain). It is hard to imagine a workable combination in this double choice, that would avoid the party remaining in the centre of the political spectrum, where it runs a great risk to loose electorate both to the left and the right. In contrast, the results of the Greens was disappointing, certainly if 
compared with the success of Ecolo (the French speaking Greens) in Brussels and Wallonia. Even if this is not the reason of their weakness, the Greens didn't play the card of urbanism to buttress their geopolitical position in Flanders.

\section{Urbanism as a way of hope}

42 In Marxist urban geography and sociology, the city is regarded as a spatial concentration of social surplus (Harvey, 1973). For Louis Wirth a city is defined by size, density and heterogeneity (1938). Although Wirth developed a largely negative image of the city when exploring urban behaviour on the basis of these features, their combination with Harvey's concentration process yields a relevant and much more positive insight in the nature of urbanism. The density of Wirth's definition refers to concentration; size is achieved by accumulation of wealth; heterogeneity results from the fact that wealth exonerates urban dwellers from direct self-sufficient production. As a result, cities concentrate many people who can think, create, dream, write, innovate, manage or decide. All this works much better because they are not sitting in ivory towers, but clustered together in a place where information and channels of communication converge.

This very basic description of the nature of urbanism reveals the social consequences of anti-urbanism and what is at stake with the political expansion of extreme-right in Flanders. Bluntly speaking, anti-urbanism has generated a Flemish intellectual poverty. The problem could be traced to the counter-reformation, which chased the brightest minds from our cities away to the north. The socio-linguistic frontier has prevented the development of standardised Dutch and linked the language with all its local variations to the peasant and later working class status. The bourgeoisie, however, adopted French and any social promotion was associated with a shift to the French language, even after the Second World War. As a result, the Flemish intellectual potential - which did indeed flourish in the cities - was deeply embedded in French culture.

Since then, anyone who had the opportunity to form part of a Flemish intellectual class was all-too-often crippled by the partitioned character of his non-urban residential environment (Laermans, 1993). One hundred and twenty years of obsession precisely with spreading the emancipating layers of the population outside the cities have established a partitioning of communication, information and social relationships, which leads to something like a "Readers' Digest intellectualism", uniform, ready-made and rigid, preventing all questioning of a paternalistic common sense. Scattered in their "fermettes" (pseudo small farmhouses)( $\left.{ }^{14}\right)$, the Flemish middle classes never turned towards the cities to satisfy their curiosity and creativity.

The hope for more emancipating power and a brighter intellectual future of Flanders is related to the recent economic and socio-cultural history of the Region. A sound intellectual class in Flanders is only now emerging. While in the 60s and 70s, broadly speaking 20 to $30 \%$ of the university students would have parents with some form of higher education, they are the majority today. Meanwhile, both the numbers of university students and of university degree holders were multiplied by five between 1960 and $1991^{15}$. These young (potential) intellectuals need the cities in order to fulfil their aspirations and some welcome, but tentative signs of change are evident. For instance, Leuven student associations are increasingly organising outings to Brussels, while some choose to stay on in Brussels after their studies, rather than in Leuven. The 
idea of giving Brussels' students more of a base in the city is under consideration and a consortium of universities and high schools is creating a type of "Quartier Latin" in Brussels. Proportionally speaking, foreigners are also choosing Brussels in preference to the suburban areas of Brabant; these most probably include the second generation of the first EU civil servants who settled in the suburbs of Brussels in the 60 s and 70s, as well as the younger newcomers arriving to swell the ranks of Eurocrats following expansion of the Union and of its powers, or to take up the generated employment in other sectors (Kesteloot e.a., 2000).

The geographical dispersal of wealth implied by anti-urban politics also explains the relatively high concentration of poverty in cities, particularly in the 19th century belt, which has carried the slur of intimidation since its inception ("insecurity" in current terms). The urban immigrant workers (i.e. the large majority of them if one excludes the Limburg mining area) originally filled in the economic and spatial gaps created by the upward social mobility of the Flemings. Indeed, the expansion of the Flemish middle class and its transfer to the non-urban areas explain the concentration of immigrants in the low-paid and low-skilled positions of the urban labour market and in the abandoned inner city working class neighbourhoods. Such a socio-spatial contrast between the inner cities and large suburban areas is dramatic when the financial resources of the cities are mainly determined by local incomes (De Brabander e.a., 1987). Indeed, the population that benefits from the city because it finds its employment there and uses the urban amenities, pays its local taxes in the suburban municipalities. Meanwhile, the urban municipalities, which finance the collective goods and services for these city users, face a decline of their fiscal basis through the decrease of their own population. Continuous deindustrialisation since the sixties, the economic crisis of the seventies and eighties and the socio-spatial polarisation of the nineties have driven the former urban working class into poverty and desperation. In such circumstances, this residual voting population of the inner cities is easily dazzled by the Vlaams Blok scapegoat and security discourses, without understanding its anti-urban character. The same socio-spatial process equally underpins the distancing stances on which the Vlaams Blok builds its electoral successes in the suburbs (Kesteloot \& De Decker, 1992). The study of the socio-spatial structure of Flanders and its geopolitical change suggests that the rise of extreme-right outside the inner city neighbourhoods is not just the result of erratic behaviour of part of the electorate, nor of a particularly strong persuasion ability of the Vlaams Blok. It is a symptom of the interdependent fears of the city and of difference, deeply rooted in the Flemish middle class. The economic crisis caused a surge of social exclusion that materialised in a double otherness in the Flemish mentality: that of the city and of the immigrant. The Vlaams Blok precisely takes advantage of the mutual reinforcement of the fear of the city and the fear of the immigrant. However, few political critics came to the insight that the struggle against extreme-right does not only require resistance to racism (and its close parent sexism), but also the struggle for the city and for urbanism in a profound anti-urban Flanders Region. This is also the only solution for the scapegoat stances that develop in the inner city neighbourhoods. 


\section{BIBLIOGRAPHY}

CHOAY F. (1965), L'urbanisme, utopies et réalités, une anthologie, Paris, Editions du Seuil.

DE BRABANDER G., VERVOORT L. \& WITLOX F. (1987), Metropolis, over mensen, steden en centen, Leuven, Kritak.

DE MAESSCHALCK F. (2000), "Electo-rale gografie van het Vlaams Blok. De ruimtelijke evolutie van de verkiezings-uitslagen van 1981 tot en met 1995", De Aardrijkskunde, 24, 1-2, pp.21-36.

DE RIJCK T. \& VAN MEULDER G. (2000), De ereburgers - een sociale geschiedenis van de Limburgse mijnwerkers, Berchem, EPO.

DE SMET R. E. \& EVALENKO R. (1956), Les élections belges. Explications de la répartition géographique des suffrages, Bruxelles, Editions de l'Université de Bruxelles.

FRANKEN E. (1988), “De O.L.V.-ter Sneeuwwijk: een Haussmannisatieproces te Brussel”, Tijdschrift van de Belgische Vereniging voor Aardrijkskundige Studies, 2, pp.285-302.

GERARD E. (1998), “The Christian workers' movement as a mass foundation of the Flemish movement”, in DEPREZ K. \& VOS L. (eds.), Nationalism in Belgium, shifting identities 1780-2000, Antwerp, Houtekiet, pp.127-138.

GOOSSENS L. (1983), "Het sociaal huisvestingsbeleid in België sinds 1830", in KONING BOUDEWIJN STICHTING (ed.), Sociaal woonbeleid, Brussel, Koning Boudewijn Stichting, pp.12-31.

GREENACRE M. \& BLASIUS J. (eds.) (1994), Correspondence analysis in the social sciences, New York, Academic Press.

HARVEY D. (1973), Social justice and the city, London, Edward Arnold.

JOHNSTON R.J. (1990), “Lipset and Rokkan revisited: electoral cleavages, electoral geography, and electoral strategy in Great Britain”, in JOHNSTON R.J., SHELLEY F.M. \& TAYLOR P.J. (eds.), Developments in Electoral Geography, London, Routledge, pp. 121-142.

JOYE P. \& LEWIN R. (1967), L'Eglise et le mouvement ouvrier en Belgique, Bruxelles, Société Populaire d'Editions.

KESTELOOT C. \& DE DECKER P. (1992), "Territoria en migraties als geografische factoren van racisme”, in DESLÉ E. \& MARTENS A. (eds.), Gezichten van het hedendaags racisme, Brussel, VUBPress, pp. 69-108.

KESTELOOT C., PELEMAN K. \& VAN DER HAEGEN H. (2000), “The changing geography of foreigners in Belgium, 1991-1999: the impact of population and nationality changes", Tijdschrift van de Belgische Vereniging voor Aardrijkskundige Studies, 69, 2, pp. 313-348.

LAERMANS R. (1993), De lege plek: opstellen over cultuur en openbaarheid in de provincie Vlaanderen, Leuven, Kritak.

MOUGENOT C. (1988), "Promoting the single family house in Belgium: the social construction of model housing", International Journal for Urban and Regional Research, 12, pp. 531-549.

SAEY P., KESTELOOT C. \& VANDER-MOTTEN C. (1999), "Unequal economic development at the origin of the federalisation process", in DEPREZ K. \& VOS L. (eds.), Nationalism in Belgium, shifting identities 1780-2000, Antwerp, Houtekiet, pp.165-176. 
SMEDTS, D. (1998), Evolutie in de sociale herkomst van de studenten-populatie K.U.Leuven 1964-1995, Leuven, K.U.Leuven

SMETS M. (1977), De ontwikkeling van de tuinwijkgedachte in België, een overzicht van de Belgische volks-woningbouw 1830-1930, Liège, Mardaga.

SWYNGEDOUW E. (1990), "L'espace, le fordisme et le Limbourg”, in MORT-SUBITE, Les

fractionnements sociaux de l'espace belge, une géographie de la société belge, Bruxelles, Contradictions, $\mathrm{n}^{\circ} 58-59, \mathrm{pp} .115-151$.

SWYNGEDOUW, M. \& BEERTEN R. (1999), De fragmentatie van het kiezers-korps in Vlaanderen. Verschuivingen 1991-1995 en 1995-1999, ISPO Bulletin 1999/34, Leuven, Interuniversitair Steunpunt Politieke Opinieonderzoek.

TAYLOR, P.J. (2000), Political Geography, world economy, nation-state and locality, Harlow, Pearson Education.

VAN DER HAEGEN H. (1982), “Honderd jaar pendel naar Brussel, evolutie en evaluatie”, De Aardrijkskunde, 2, pp.119-128.

VANDERMOTTEN C. DECROLY J.M., DESSOUROUX C. \& ROUYET Y. (2001), "Permanences et ruptures dans les temps longs de la géographie électorale de la Belgique”, Belgeo, 1-2, pp. 7-40.

VANDERMOTTEN C., SAEY P. \& KESTELOOT C. (1990), "Les fragments de la Belgique: la Wallonie et la Flandre existent-elles vraiment?", in MORT-SUBITE, Les fractionnements sociaux de l'espace belge, une géographie de la société belge, Bruxelles, Contradictions, n58-59, pp.7-67.

VANDERMOTTEN C., VERMOESEN F., DE LANNOY W. \& DE CORTE S. (1999), “Villes d'Europe. Cartographie comparative”, Bruxelles, Bulletin du Crédit Communal de Belgique, 53, 207-208.

VANLAER J. (1984), 200 Millions de voix, une géographie des familles politiques européennes, Bruxelles, Société Royale Belge de Géographie et Laboratoire de Géographie Humaine de l'Université Libre de Bruxelles.

WIRTH L. (1938), “Urbanism as a way of life”, The American Journal of Sociology, 44, 1, pp. 1-24; reprinted in PRESS I. \& SMITH M.E. (eds.) (1980), Urban place and process, readings in the anthropology of cities, New York, Macmillan, pp.30-48.

WITTE E. (ed.) (1993), De Vlaamse Rand, Brussel, VUB-Press.

\section{NOTES}

1. Some explanation is needed about the federal arrangement of the Belgian State in order to understand the relations between Flanders and Brussels. Belgium consists of 3 territorial regions: the Flemish, the Walloon and the Brussels Capital Region, each with its own government. In addition, there are the French and the Flemish Community that overlap in the Brussels Capital Region (and a small German-speaking community in the Walloon Region). The Flemish Regional Government and the Flemish Community Government are merged.

2. Brussels has 950.000 inhabitants and $35 \%$ of them live in deprived areas. In comparison Antwerp has 450.000 inhabitants, of whom $21 \%$ in deprived areas. In Ghent they are $16 \%$ of 225.000 inhabitants. However, one could advocate that the Social Impulse Fund only concerns the Flemish Community in Brussels. Although there is no language census, between 15 and $20 \%$ of the Brussels population can be considered as Flemish.

3. The Vlaams Blok is an extreme-right Flemish nationalist party. The Brussels Capital Region Government is based on a double majority in the French and the Flemish communities of the 
Region. With a majority in the Flemish community, the party could block the Brussels Region and jeopardize the whole Belgian federal construction. Recently, one of their MP's proposed to block all communications from and to Brussels and to economically asphyxiate the city in order to force it to join the future Flemish State (geographically, Brussels is an enclave in the Flemish Region).

4. Interestingly, the Walloons have developed a parallel aversion to Brussels because Walloon industry was controlled by Brussels bankers and shareholders. For them, Brussels bears responsibility for the downturn in the Walloon economy.

5. In literature, anti-urbanism is mostly associated with the United States that built its nationstate on westward rural colonisation, rather than on industrialisation and urbanisation. In the present context, it refers to the general aversion of the large city, which is more in line with the critique of the industrial city. But the latter is not necessarily anti-urban (Choay, 1965).

6. There are a few exceptions, largely restricted to cities in the province of East-Flanders. Ghent is by large the most important. The trade unions and other workers' movement institutions first originated in Ghent, but they never reached a political influence like in Wallonia.

7. These dangers were at the origin of Haussmannisation projects in most of the large Belgian cities in the last quarter of the 19th century. While the sanitation effect was significant, these projects aimed at bringing the bourgeoisie back to the city (with poor success), and the side effect was that a part of the working class was further driven out (others were concentrated in the remaining urban working class areas, see Franken 1988 for the Brussels case).

8. In terms of population, Amsterdam is one-quarter smaller than Brussels but the commuter zone is barely $1000 \mathrm{~km}^{2}$, compared to $4400 \mathrm{~km}^{2}$ for Brussels. The ratio between the total area of the functional urban system and the population of the urban agglomeration is 0,53 ha per urban inhabitant, compared to 0,33 for Frankfurt, 0,22 for Paris and less than 0,2 for Lille, London and the Ruhr. For Randstad Holland the ratio is 0,11 ha per urban inhabitant (calculated from Vandermotten e.a. 1999).

9. A detailed description of these structures can be found in De Smet \& Evalenko (1956), see also Vandermotten e.a. (2001).

10. Before the last elections, the VU made an alliance with a new party (ID21) advocating 'social liberalism'.

11. The electoral canton of Genk, the centre of the Limburg mining region, falls just into the 'urban region'.

12. The acronym of the Liberals changed from PVV to VLD between the two elections (interestingly from Party for Freedom and Progress to Flemish Liberal Democrats).

13. This term is the most accepted to name the population stemming from the labour migrations from the 60s and 70s. It implies that they are still on the move and not definitely settled. Even the second and third generation are called migrants, although they didn't participate to any migratory movement. The Vlaams Blok has preferred for a long time the term 'guestworkers', denoting their opinion that they are invited persons who should go back home as soon as the purpose of their visit has been exhausted.

14. This is literally the Dutch term for the most frequent architectural style in the dispersed residential estates. It loosely refers to the small isolated farms of the Flemish rural core area, as if fear of the city had to materialise in a false espousal of a vanished, but mythical rurality (the psychoanalysis of the 'fermette' style is still to be carried out).

15. At the Catholic University of Leuven, the largest one in Flanders, $26 \%$ of the students had parents with high education in 1964 against 61\% in 1995. Combined with the overall increase of the student population, this group experienced a sixfold increase, with more than 15.000 students in 1995. Moreover, there was a huge majority of male students in 1964 against a fair gender balance in since the 90s. (Smedts, 1998). 


\section{ABSTRACTS}

Class struggle resulted in a anti-urban feeling in Flanders. The industrial revolution first developed in Wallonia and industrialisation came much later in Flanders. The bourgeoisie and the Church could anticipate rising secularisation and socialism in Flanders by keeping the workers away from the cities through specific housing and mobility policies. This explains the traditional Christian political hegemony in Flanders, with socialist and liberal cracks mainly in the cities. In the second part of the paper the geography of the last parliamentary elections is considered. In the light of anti-urbanism, the elections produced important spatial shifts. The Christian party is replaced by the Liberals in the core of Flanders. In the cities, the Socialists are in decline, in favour of the greens and the extreme-right, the latter being also increasingly successful in the suburban fringe and the non-urban areas. In the last part, it is argued that the regressive cultural effects of anti-urbanism, but also the struggle against extreme-right, impose that urban policies should be put higher on the Flemish political agenda.

La lutte des classes a produit un sentiment anti-urbain profond en Flandre. La révolution industrielle s'est d'abord manifestée en Wallonie et l'industrialisation de la Flandre est plus tardive. La bourgeoisie et l'Église ont pu anticiper la montée de la sécularisation et du socialisme en maintenant les ouvriers hors des villes par les politiques du logement et de la mobilité. Cela explique l'hégémonie politique traditionnelle des Chrétiens en Flandre avec quelques failles socialistes ou libérales, surtout dans les villes. La seconde partie de l'article considère la géographie des dernières élections parlementaires. A la lumière de l'anti-urbanisme, ces élections présentent des changements spatiaux importants. Au cœur de la Flandre, les libéraux ont remplacé les chrétiens. Dans les villes les socialistes perdent en faveur des verts et de l'extrême-droite qui gagne aussi dans les franges urbaines et les zones non-urbaines. En conclusion, tant les effets culturels régressifs de l'anti-urbanisme que la lutte contre l'extrêmedroite imposent une plus grande priorité pour les politiques urbaines en Flandre.

\section{INDEX}

Mots-clés: anti-urbanisme, géographie politique, Flandre

Keywords: anti-urbanism, political geography, Flanders

\section{AUTHORS}

\section{CHRISTIAN KESTELOOT}

Instituut voor Sociale en Economische Geografie, Katholieke Universiteit Leuven, chris.kesteloot@geo.kuleuven.ac.be 


\section{FILIP DE MAESSCHALCK}

Instituut voor Sociale en Economische Geografie, Katholieke Universiteit Leuven,

Filip.DeMaesschalck@geo.kuleuven.ac.be 